\title{
TOLERANCE PORTRAITS IN KUPANG CITY BASED ON DIMENSIONS OF PERCEPTION, ATTITUDE, COOPERATION, AND GOVERNMENT ROLE
}

JEFIRSTSON RICHSET RIWUKORE*,FELLYANUS HABAORA*,FAKHRY ZAMZAM*, AND TIEN YUSTIN I*

${ }^{1 *}$ Universitas Indo Global Mandiri. Jl. Jenderal Sudirman, No.62, Kota Palembang, Sumatera Selatan, Indonesia

\begin{abstract}
Humans were influenced by perceptions, attitudes, cooperation, and the government roles to portray indicators of religious tolerance. Therefore, this study was carried out between January and March 2020 to deeply analyze the dimensions of perception, attitude, cooperation, and the roles of the government, using a case study technique with a descriptive approach. The population of this study were 53 people representing religious figures, community leaders, government, and levels of society. A questionnaire was used containing statements based on Likert scale measurements. Data analysis was carried out in a narrative manner. The results showed that the portrait of the dimensions of perception, attitude, cooperation, and the role of the government supports religious tolerance in the City of Kupang. However, it found that a neutral attitude was shown when it was related to the attendance to the worship of other religions. Based on the dimension of cooperation, there were also people who showed a neutral attitude on the donations or social action for the followers of other religions, and a willingness to maintain a normative business that does not conflict with adherents of other religions.
\end{abstract}

KATA KUNCI: tolerance, perceptions, attitudes, cooperation, government role, religious conflict

\section{POTRET TOLERANSI DI KOTA KUPANG BERDASARKAN DIMENSI PERSEPSI, SIKAP, KERJASAMA, DAN PERAN PEMERINTAH}

\begin{abstract}
Abstrak
Unsur manusia yang dipengaruhi oleh persepsi, sikap, kerjasama dan peran pemerintah merupakan indikator potret terhadap toleransi umat beragama. Untuk hal tersebut maka telah dilakukan penelitian sejak Januari-Maret 2020 tentang potret dimensi persepsi, sikap, kerjasama, dan peran pemerintah, menggunakan teknik studi kasus dengan pendekatan secara deskriptif. Populasi ataupun sampel dalam penelitian ini sebanyak 53 orang sebagai representatif tokoh-tokoh agama, tokoh-tokoh masyarakat, pemerintahan, dan lapisan masyarakat. Metode survei menggunakan kuesioner yang berisi pernyataan berbasis pengukuran skala Likert. Analisis data dilakukan secara naratif. Hasil penelitian menunjukkan bahwa potret dimensi persepsi, sikap, kerjasama, dan peran pemerintah mendukung toleransi umat beragama di Kota Kupang. Meskipun demikian masih ada sikap umat beragama yang netral jika terkait dengan kesediaan berada di rumah ibadah pemeluk agama lain yang ada di sekitar tempat tinggal. Berdasarkan dimensi kerjasama, juga terdapat umat yang menunjukkan sikap netral terhadap kesediaan memberikan sumbangan atau aksi sosial kepada pemeluk agama lain, dan kesediaan untuk menjaga normatif usaha yang tidak bertentangan dengan pemeluk agama lain.
\end{abstract}

KATA KUNCI: toleransi, persepsi, sikap, kerjasama, peran pemerintah, konflik agama

${ }^{*}$ Naskah diterima Februari 2020, direvisi April 2020, dan disetujui untuk diterbitkan Mei 2020 


\section{A. Pendahuluan}

Ciri khas utama kehidupan manusia adalah makhluk sosial, yaitu selalu ada interaksi manusia yang satu terhadap manusia lainnya yang diatur dengan seperangkat norma dan etika hidup sebagai manusia. Apabila terjadi pelanggaran terhadap norma dan etika hidup dimungkinkan adanya konflik. Menurut Suryana (2011), konflik dapat terjadi karena ada perbedaan persepsi, sikap, hubungan kerjasama, harapan, dan/atau terhadap pengaruh sikap pemerintah. Salah satu contoh konflik karena perbedaan tersebut dan bersifat destruktif adalah konflik karena berbeda agama.

Konflik karena berbeda agama atau sering disebut konflik agama bersifat destruktif karena merugikan bangsa dan negara termasuk manusia agama itu sendiri seperti mengganggu stabilitas politik, perekonomian bangsa, peradaban sosial dan budaya, dan manusia beragama tentunya hidup dalam suasana ketidakpastian, ketakutan, dan saling mencurigai di antara pemeluk agama.

Untuk menghindari adanya konflik agama, tentunya ciri khas utama hidup manusia sebagai makhluk sosial terus dijaga dan dipelihara karena interaksi sosial yang terjadi di antara manusia memiliki implikasi terhadap persepsi, sikap, hubungan kerjasama, harapan, dan/atau terhadap pengaruh manusia terhadap sikap pemerintah. Apabila interaksi sosial yang terjadi bersifat positif, hasilnya pun positif, dan sebaliknya bersifat negatif apabila interaksi sosial yang ada tersebut berkategori negatif. Choli (2018) menyatakan bahwa manusia perlu mempertahankan interaksi di antara makhluk sosial untuk mempertahankan keberadabannya. Ajahari (2018) menyatakan bahwa kerukunan umat manusia sebagai makhluk sosial tercapai apabila ada dialog dan kerjasama di antara umat manusia tanpa melihat perbedaan, membalas perbuatan buruk dengan nilai kebaikan, partisipasi berbasis rasa kemanusiaan, dan saling menghargai agama umat lain (toleransi). Apabila muncul ketidakpedulian dan kepasifan dalam usaha mencapai kerukunan umat manusia sebagai ciri makhluk sosial tersebut dimungkinkan awal adanya konflik dan ketegangan di antara manusia beragama atau masyarakat yang plural (Kasselstrand, 2018).

Salah satu wilayah administrasi otonomi di Indonesia yang sedang bertumbuh dan berkembang keberagaman etnis dan agama adalah di Kota Kupang, namun perkembangan keberagaman tersebut jarang atau tidak pernah memunculkan konflik berbasis agama. Hal ini seperti yang dilaporkan Parera \& Marzuki (2020) bahwa keberagaman agama di Kota Kupang tidak mempengaruhi kerukunan umat beragama, bahkan semakin kuat terpelihara karena adanya pengaruh kearifan lokal seperti nusi (gotong royong), butukilat (ikat dan pegang rasa persaudaraan), suki toka apa (mendukung dan menolong), muki nena (rasa memiliki dan mempunyai), dan selalu hidup atas falsafah pembangunan Lil Au Nol Daen Banan (membangun dan menjaga Kota Kupang adalah tugas semua warga yang ada di dalamnya tanpa memandang agama, suku, maupun ras).

Keberagaman yang semakin menguatkan kerukunan umat beragama di Kota Kupang diharapkan menjadi potensi yang menambah daya toleransi tinggi, tetapi juga dikuatirkan menyimpan potensi konflik keberagaman. Hal ini seperti yang dinyatakan oleh Hermawati et al. (2017) bahwa kota dengan ciri keberagaman sosial dan budaya menyimpan konflik dari sumber keberagaman tersebut, dan salah satu sumber konflik yang rentan terjadi adalah konflik karena perbedaan agama.

Dugaan konflik karena perbedaan agama dimungkinkan terjadi karena di Kota Kupang pernah terjadi perselisihan antara sesama warga tetapi meluas menjadi konflik agama. Daeli \& Zaluchu (2019) melaporkan bahwa pada tanggal 30 November 1998, di Kota Kupang, beberapa masjid, rumah-rumah bugis dan toko-toko dibakar, dan orang Muslim hidup dalam kecemasan dan ketakutan. Pasca konflik, interaksi umat beragama kembali terpelihara dan semakin tinggi toleransi. Hal ini wajib dipelihara secara terus menerus, dan apabila kerukunan umat beragama ini tidak diperlihara secara baik, apalagi konflik pernah terjadi, dimungkinkan akan kembali terjadi konflik.

Rasa ketidakpuasan pascakonflik atau trauma masa lalu akibat konflik dimungkinkan akan mengganggu persepsi, sikap, hubungan kerjasama, harapan, termasuk sikap pemerintah terhadap pemeluk agama. Jika keseluruhan dimensi tersebut lebih berorientasi kepentingan individu atau kelompok identitas, tentunya akan memunculkan konflik lagi. As'ad (2018) menyatakan bahwa konflik tidak berlangsung 
selamanya karena pasti ada penyelesaiannya, tetapi berlangsung hanya sementara waktu karena rasa ketidakpuasan dari akibat yang ditimbulkan pascakonflik. Rahmawati Zulfiningrum1, Akbar Nuur Purnawa DW2, (2020) menyatakan bahwa potensi konflik dalam masyarakat dapat terjadi apabila pemikiran dan interaksi sosial dan budaya dipenuhi oleh prasangka, kebencian, dan keraguan (kesadaran timbal balik) terhadap orang lain karena kontradiksi yang primitif dan mengancam. Dimensi Pemikiran sosial dan budaya dalam interaksi sosial umat beragama tersebut akan tergambar dalam persepsi, sikap, hubungan kerjasama, harapan publik, termasuk terhadap sikap pemerintah. Dengan demikian rumusan masalah dalam penelitian ini adalah bagaimanakah dimensi persespi, sikap, hubungan kerjasama, harapan publik, dan sikap pemerintah terhadap perbedaan agama? Dengan demikian tujuan dari penelitian adalah memahami dan mengetahui dimensi persepsi, sikap, hubungan kerjasama, harapan publik, dan sikap pemerintah terhadap perbedaan umat beragama.

\section{B. Metode Penelitian}

Penelitian ini tergolong jenis penelitian eksplanatif terhadap potret toleransi umat beragama berdasarkan dimensi persepsi, sikap, kerjasama, dan peran pemerintah. Penelitian dilakukan di Kota Kupang Nusa Tenggara Timur (NTT) dengan pendekatan deskriptif (kuantitatif dan kualitatif). Pengumpulan data dilakukan pada tanggal 1 Januari sampai 15 Maret 2020. Informan dalam penelitian ini sebanyak 53 orang, meliputi tokoh-tokoh agama, tokoh-tokoh masyarakat, pemerintahan, dan lapisan masyarakat. Teknik memperoleh data dilakukan menggunakan observasi, wawancara menggunakan kuisioner, dan dokumentasi.

Dimensi penelitian adalah persepsi, sikap, kerjasama, dan peran pemerintah yang dirumuskan dalam item-item pernyataan dalam kuisioner. Indikator yang memperlihatkan dimensi di atas diberi bobot, mulai dari yang paling rendah sampai yang paling tinggi. Jawaban pada kuisioner, responden diminta memilih salah satu dari 5 jawaban, yakni SS (sangat setuju), S (setuju), N (netral), TS (tidak setuju), dan STS (sangat tidak setuju) dengan masing-masing skor persentase. Pembobotan seperti ini merujuk pada Skala Likert yang lazim digunakan dalam penelitian survei. Hasil perhitungan tersebut selanjutnya dianalisis dengan menginterpretasikan skor nilai persentase. Dalam interpretasi tersebut, juga digunakan hasil pengolahan data secara deskriptif.

\section{Hasil dan Pembahasan \\ Persepsi Umat Beragama}

Dalam tindakan sosial atau sikap yang muncul, persepsi atau penilaian biasanya mendahului tindakan tersebut. Hermawati et al. (2017) menyatakan bahwa persepsi biasanya mendorong lahirnya sikap atau bahkan tindakan yang dipengaruhi norma yang dimiliki manusia beragama. Uji persepsi umat beragama di Kota Kupang dapat dilihat pada Tabel 1, yaitu terdiri atas: (1) agama yang dianut paling benar, hasilnya adalah sebagian besar pemeluk agama menyatakan sangat setuju $(76,2 \%)$ dan setuju $(13,1 \%)$, dan hanya sebagian kecil yang menyatakan tidak setuju dan sangat tidak setuju; (2) umat bebas ekspresi tanpa norma berekspresi, hasilnya: sebagian besar responden sangat tidak setuju $(81,9 \%)$ dan tidak setuju $(5,7 \%)$ atau sebagian kecil saja yang sangat setuju dan setuju; (3) minoritas mengikuti kehendak mayoritas, hasilnya: seluruh responden tidak menyetujui pernyataan tersebut; (4) agama wajar digunakan dalam isu politik, dan hasilnya: sebagian responden sangat setuju dan setuju, meskipun sebagian kecil responden menolak pernyataan tersebut; (5) interaksi sosial berbasis agama, dan hasilnya: pernyataan ini ditolak oleh seluruh responden; (6) euforia acara keagamaan sangat wajar, dan hasilnya sebagian besar responden sangat setuju dan setuju $(>85,2 \%)$, tetapi terdapat sebagian kecil responden $(0,3-0,5 \%)$ yang menolak pernyataan tersebut; dan (7) doktrin agama berbasis kekerasan dijinkan, dimana pernyataan ini ditolak (sangat tidak setuju) oleh seluruh responden

Persepsi responden yang menyatakan bahwa agama mereka dianggap paling benar mengindikasikan adanya klaim keagamaan dan pengajaran, sedangkan responden yang berpersepsi bahwa agama belum tentu benar mengindikasikan persepsi responden bahwa agama tidak penting dipermasalahkan dalam kehidupan sehari-hari. Setiap agama selalu mengajarkan nilai-nilai kebaikan, termasuk di dalamnya adalah toleransi dan pluralisme 
sehingga manusia yang menganggap agamanya paling benar akan selalu melaksanakan sesuai ajaran agamanya, sedangkan sebagian orang menganggap bahwa manusia hidup wajib berdampingan sebagai makhluk sosial dalam interaksi sosial budaya sehari-hari. Hafidzi (2019) menyatakan bahwa setiap agama mengakui adanya konsep pluralisme keyakinan dan pengajarannya (internal), dan toleransi diyakini karena kematangan sikap dalam beragama dan kematangan beradaptasi (eksternal).

Sebagian besar responden menganggap bahwa setiap umat beragama memiliki kebebasan dalam berekspresi tetapi dalam batas-batas norma seperti etika kemasyarakatan, meskipun masih terdapat sebagian kecil responden yang menganggap ekspresi keagamaan sebagai hal yang mutlak dan bebas. Pada umumnya, perilaku dalam interaksi sosial muncul kebiasaan saling memahami dalam kebiasaan arif, dimana pemeluk agama telah memiliki sikap memahami kebebasan ekspresi umat beragama lain dengan kelebihan dan kekurangannya, tetapi hal tersebut tetap dibatasi kebiasaan-kebiasaan yang berlaku di wilayah setempat. Hal inilah yang memunculkan perbedaan persepsi antara batasan ekspresi yang dibatasi norma dan kebebasan mutlak dalam berekspresi. Putra \& Yuliando (2015) menyatakan bahwa faktor sosial budaya dipengaruhi kesamaan wilayah tempat tinggal, hubungan kekerabatan, toleransi, kedudukan dalam masyarakat, kepentingan ekonomi, kesadaran diri, dan pendidikan.

Tabel 1. Persepsi umat beragama

\begin{tabular}{|l|c|c|c|c|c|}
\hline \multicolumn{1}{|c|}{ Persepsi } & \multicolumn{5}{|c|}{ Jawaban (\%) } \\
\cline { 2 - 6 } & SS & S & N & TS & STS \\
\hline $\begin{array}{l}\text { Agama yang diantıt } \\
\text { paling benar }\end{array}$ & 76,2 & 13,1 & 3,7 & 5,2 & 1,8 \\
\hline $\begin{array}{l}\text { Umat tanpa } \\
\text { ekspresi } \\
\text { norma berekspresi }\end{array}$ & 4,3 & 6,8 & 1,3 & 5,7 & 81,9 \\
\hline $\begin{array}{l}\text { Minoritas } \\
\text { mengikuti } \\
\text { kehendak mayoritas }\end{array}$ & - & - & - & 0,8 & 99,2 \\
\hline $\begin{array}{l}\text { Agama sangat wajar } \\
\text { digunakan dalam } \\
\text { isu politik sosial }\end{array}$ & 64,3 & 17,9 & 1,5 & 7,4 & 8,9 \\
\hline $\begin{array}{l}\text { Interaksi acara } \\
\text { berbasis agama } \\
\text { Euforia }\end{array}$ & - & - & - & - & 100 \\
\hline $\begin{array}{l}\text { keagamaan sangat } \\
\text { wajar }\end{array}$ & 85,2 & 11,3 & 2,7 & 0,3 & 0,5 \\
\hline $\begin{array}{l}\text { Doktrin keagamaan } \\
\text { berbasis kekerasan } \\
\text { diijinkan }\end{array}$ & - & - & - & - & 100 \\
\hline
\end{tabular}

Persepsi responden yang seluruhnya menolak pernyataan bahwa minoritas mengikuti kehendak mayoritas menunjukkan adanya sikap toleransi tinggi dan masing-masing pemeluk agama tidak saling mendiskriminasi. Hal ini menunjukkan bahwa adanya kesaling pengertian dan saling melindungi di antara pemeluk agama, yakni dari mayoritas terhadap minoritas atau sebaliknya. Hal ini seperti yang dilaporkan oleh Tule (2014) bahwa saat terjadi konflik agama di Kota Kupang, perlindungan terhadap penduduk yang beragama Muslim dilakukan oleh penduduk nasrani, meskipun awalnya konflik yang menjadi sasaran adalah suku Bugis yang akhirnya meluas berbasis agama. Nasution (2017) menyatakan bahwa meskipun banyak kejadian konflik atau penindasan yang berbasis mayoritas terhadap minoritas, tidak menjadi kendala untuk wilayahwilayah di Indonesia yang telah memiliki sikap toleransi yang kuat, seperti di Kota Kupang.

Sebagian besar responden mengungkapkan bahwa agama sangat wajar digunakan dalam isu politik. Berbagai pertimbangan dalam menentukan pilihan politik, salah satunya adalah agama. Hal ini juga dimaknai sebagai keterwakilan masyarakat. Seperti yang terjadi di politik kepala daerah di Kota Kupang, Walikotanya sudah tentu beragama Kristen sebagai mayoritas, dan Katolik atau Islam sebagai Wakil Walikota-nya. Tetapi dalam isu politik ini hanya sebatas untuk kepentingan pemenangan pemilu, tidak menjadi basis dalam interaksi sosial masyarakat sehari-hari. Meskipun demikian, masih terdapat sebagian kecil responden yang tidak menyetujui agama digunakan dalam isu politik.

Responden seutuhnya menolak adanya persepsi bahwa interaksi sosial berbasis agama. Hal ini mengindikasikan bahwa secara sosial budaya masyarakat di dalam kehidupan seharihari tidak dibatasi lagi oleh kesenjangan agama atau perbedaan agama, yang umum dikenal dengan istilah toleransi sosial atau toleransi kemasyarakatan (Nisvilyah, 2010).

Sebagian besar responden berpersepsi bahwa euforia acara keagamaan sangat wajar, meskipun terdapat sebagian responden yang menganggap bahwa euforia keagamaan tersebut perlu dibatasi dengan kebiasaan-kebiasan setempat. Hal ini menjelaskan bahwa euforia keagamaan yang telah biasa ada dan selalu bersentuhan dengan 
kehidupan peradaban manusia akan memunculkan toleransi, tetapi dapat berakibat buruk jika euforia keagamaan yang dilakukan terlihat baru dan atau belum bersentuhan dengan kebiasaan hidup sehari-hari penduduk setempat. Hermawati et al. (2017) menyatakan bahwa persepsi toleransi beragama cenderung positif jika perbedaan agama itu masih berada dalam jarak sosial yang tidak terlampau dekat dengan kehidupan sehari-hari responden. Sebaliknya, ketika euforia pemeluk agama lain tersebut dinilai sudah memasuki ranah kehidupan sehari-hari, misalnya dengan menyelenggarakan kegiatan bernuansa agama di sekitar lingkungan pemukiman, maka persepsi toleransi mengalami pergeseran ke arah kecenderungan penolakan.

Secara utuh responden menolak doktrin keagamaan berbasis kekerasan diijinkan. Hal ini mengindikasikan bahwa responden telah sigap dan menolak adanya ujaran kebencian yang memecah persatuan. Adanya khotbah/khutbah yang sejuk, toleran, dan moderat bisa menghindarkan dari sikap dan paham keagamaan yang fundamental. Secara umum menyampaikan ujaran atau doktrin yang bersifat mendidik dan jauh dari unsur ujaran kebencian dan menistakan prinsip kemanusiaan, paling tidak secara wacana banyak memberikan pengaruh terhadap pola perilaku umat yang menjadi pendengarnya sehingga bisa bersikap toleran dan menghargai kepada kelompok di luar dirinya (Mibtadin \& Hedi, 2020).

\section{Sikap Umat Beragama}

Eksklusivisme, inklusivisme, dan pluralisme merupakan tiga sikap umat beragama yang ditunjukkan dalam berinteraksi sosial (Hidayat, 2014). Eksklusifisme berorientasi agama yang paling benar dan yang lain sesat dan terkutuk sehingga wajib dikikis atau dikonversi pemeluknya. Inkulisivisme menganggap agama lain sebagai agama implisit atau kebenarannya tidak sesempurna yang dianut kaum inklusivisme. Pluralisme menganggap bahwa manusia perlu hidup bersama-sama tanpa ada konflik asimilasi. Ketiga sikap umat beragama tersebut dapat terlihat dalam kehidupan sehari-hari, seperti tersaji pada Tabel 2.
Tabel 2. Sikap umat beragama

\begin{tabular}{|c|c|c|c|c|c|}
\hline \multirow{2}{*}{ Sikap } & \multicolumn{5}{|c|}{ Jawaban (\%) } \\
\hline & SS & $\mathrm{S}$ & $\mathbf{N}$ & TS & STS \\
\hline $\begin{array}{l}\text { Bersedia } \\
\text { bertetangga dengan } \\
\text { pemelık agama } \\
\text { lain }\end{array}$ & 71,9 & 9,3 & 5,7 & 6,9 & 6,2 \\
\hline $\begin{array}{l}\text { Bersedia menikah } \\
\text { dengan pemelık } \\
\text { agama lain }\end{array}$ & 7,9 & 1,5 & 2,8 & 3,9 & 83,9 \\
\hline $\begin{array}{l}\text { Bersedia ada rumah } \\
\text { ibadah pemeluk } \\
\text { agama lain di } \\
\text { lingkungan tempat } \\
\text { tinggal }\end{array}$ & 0,8 & 2,6 & 93,5 & 1,4 & 1,7 \\
\hline $\begin{array}{l}\text { Terlibat dan } \\
\text { berpartisipasi } \\
\text { dalam kegiatan } \\
\text { keagamaan orang } \\
\text { lain }\end{array}$ & 83,7 & 9,4 & 6,9 & - & - \\
\hline $\begin{array}{l}\text { Menyelesaikan } \\
\text { konflik tanpa } \\
\text { memandang agama }\end{array}$ & 100 & - & - & - & - \\
\hline $\begin{array}{l}\text { Keberadaan agama } \\
\text { lain yang tidak } \\
\text { sestuai dengan } \\
\text { agama yang diakui } \\
\text { negara sangat } \\
\text { meresahkan }\end{array}$ & 93,4 & 5,1 & - & 1,5 & - \\
\hline $\begin{array}{l}\text { Merasa terganggu } \\
\text { dengan cara } \\
\text { berpakaian } \\
\text { pemelık agama } \\
\text { lain yang terkesan } \\
\text { berlebihan }\end{array}$ & 74,3 & 13,8 & 0,6 & 1,7 & 9,6 \\
\hline
\end{tabular}

Sebagian besar responden bersedia bertetangga dengan pemeluk agama lain $(>71,9 \%)$. Hal ini menunjukkan bahwa mayoritas pemeluk agama di Kota Kupang tidak mempersalahkan wilayah tempat tinggal mereka dan kondisi demografi yang terjadi. Dengan demikian dari aspek tipologi sikap, mayoritas pemeluk agama di Kota Kupang bersikap inklusif atau moderat. Hal ini seperti yang dinyatakan Darmawati H \& Abdullah (2016) bahwa umat beragama di Indonesia cenderung menunjukkan sikap moderat dan inklusifnya, yaitu ditunjukkan dengan kesediaan menerima hubungan bertetangga dengan penganut agama lain, tetapi tidak semua umat bersedia hidup bertetangga dengan penganut agama lain. 
Mayoritas responden tidak bersedia menikah dengan pemeluk agama lain (83,9\%). Umumnya, responden merasa kuatir terhadap kemungkinan kesalahpahaman dalam stabilitas rumah tangga, meskipun terdapat sebagian orang bersikap menikah beda agama bukan suatu masalah karena kunci kebahagiaan adalah rasa saling mencintai. Hutapea (2011) menyatakan perbedaan dalam kebiasaan dan kepercayaan agama dapat menimbulkan kesalahpahaman atau perselisihan dalam pernikahan yang beda agama. Umumnya, pasangan suami istri yang telah menikah bedah agama tidak menginginkan anak mereka untuk menikah dengan pasangan beda agama karena adanya pengaruh keluarga besar dan saudara mereka yang dianggap sebagai pengaruh sosial yang negatif, namun pada saat yang bersamaan juga berfungsi sebagai faktor pendukung dalam dinamika penyesuaian yang dilakukan oleh suami istri, hubungan antara anak-anak dan orang tua mereka, serta antara anak-anak sendiri. Meskipun ada pengaruh kunci dalam langgeng pernikahan beda agama yaitu komitmen individual yang didasari oleh manifesto sosiologi untuk mempertahankan pernikahan meskipun sebenarnya mereka tidak bahagia.

Mayoritas responden berusaha netral $(93,5 \%)$ untuk bersedia ada di rumah ibadah pemeluk agama lain di lingkungan tempat tinggal. Sikap yang dinetral ini kemungkinan dipengaruhi oleh persepsi bahwa tempat ibadah tidak mengganggu kenyamanan secara personal responden. Maulidah (2014) menyatakan bahwa keselarasan antara umat dalam berkegiatan ibadah jauh dari konflik karena masyarakat telah menyadari terhadap toleransi beragama sehingga mereka menanggapi keberadaan tempat gereja di lingkungannya sebagai hak umat dalam menjalankan keyakinannya.

Umumnya responden mengatakan sangat setuju $(83,7 \%)$ dan setuju $(9,4 \%)$ bahwa mereka tetap terlibat dan berpartisipasi dalam kegiatan keagamaan orang lain dan hanya sebagian kecil responden $(6,9 \%)$ yang mengatakan netral. Hal ini mengindikasikan bahwa kerjasama maupun partisipasi aktif antar umat bergama terjalin sangat baik dan tidak bersifat eksklusif. Parera \& Marzuki (2020) melaporkan bahwa keberagaman di Kota Kupang dalam kerukunan umat beragama terpelihara secara baik dikarenakan pengaruh kearifan lokal keberagaman yang selama ini telah terpelihara dengan baik.

Keseluruhan responden (100\%) mengatakan sangat setuju bahwa dalam menyelesaikan konflik tanpa memandang agama. Hal ini menjadi indikasi bahwa dalam menyelesaikan masalah atau konflik yang sedang terjadi, asas kebenaran dan keadilan tetap dijaga tanpa memandang unsur agama tertentu. Faktor ini sangat dipengaruhi oleh persepsi bahwa Indonesia dikenal sebagai negara majemuk (plural) dalam hal agama dan keyakinan dan menjadi perekat dan pengokoh bangunan negeri ini sehingga perbedaan agama tidak menjadi asas menutupi kesalahan seorang umat (Hapsin, 2014).

Hampir keseluruhan responden mengatakan sangat setuju $(93,4 \%)$ dan setuju $(5,1 \%)$ atau hanya sebagian kecil responden $(1,5 \%)$ mengatakan tidak setuju bahwa keberadaan agama lain yang tidak sesuai dengan agama yang diakui negara sangat meresahkan. Hal ini dikarenakan masyarakat Indonesia telah familiar dan terdoktrinasi dengan asas Ketuhanan yang mengakui 6 agama (Islam, Protestan, Katolik, Hindu, Budha, Konhucu) di Indonesia yang selama masa hidup sehari-hari masyarakat mengenal dan mengakui jenis agama tersebut. Mukzizatin (2019) menyatakan Ketuhanan yang dimiliki oleh bangsa Indonesia adalah Ketuhanan yang dilandasi dengan semangat toleransi yang bisa menerima keberadaan para pemeluk agama lain. Budaya toleransi inilah ciri khas semangat gotong royong/ kerjasama dari bangsa Indonesia sejak dulu kala.

Mayoritas responden mengatakan sangat setuju $(74,3 \%)$ dan setuju $(13,8 \%)$ atau hanya sebagian kecil yang mengatakan sangat tidak setuju $(9,6 \%)$ dan tidak setuju $(1,7 \%)$ bahwa umat merasa terganggu dengan cara berpakaian pemeluk agama lain yang terkesan berlebihan. Umumnya sesuatu yang tampak berlebihan atau dianggap baru dan tidak sesuai dengan tatabusana/kebiasaan di daerah setempat memunculkan sikap untuk menolak. Ahmad Fauzi (2016) menyatakan bahwa begitu hebatnya budaya dan mode dalam berbusana, membuat manusia lupa memahami hakekat dari fungsi adanya busana, dalam arti busana selain bersifat lokal, juga dapat diterima dimanapun (universal) terutama jenis busana keagamaan. Masalah yang paling sering menimbulkan salah paham adalah anggapan kebanyakan orang terhadap busana keagamaan yang telah dikenal umum dianggap 
kampungan, ketinggalan zaman, tidak modern, out of date.

\section{Kerjasama Umat Beragama}

Deskripsi kerjasama umat beragama di Kota Kupang tampak pada Tabel 3, yaitu: (1) sebagian besar responden $(>65,2 \%)$ bersedia mengajak pemeluk agama lain agar terlibat dalam kegiatan yang diadakan; (2) umumnya umat beragama netral $(65,8 \%)$ apabila ditanya kesediaan memberikan sumbangan atau aksi sosial kepada pemeluk agama lain; (3) sebagian besar responden $(49,4 \%)$ bersedia terlibat dalam pembangunan rumah ibadah pemeluk agama lain; (4) seluruh responden $(100 \%)$ bersedia memberikan izin kepada pemeluk agama lain untuk berkegiatan yang tidak meresahkan banyak orang; (5) antara $80,6-99,1 \%$ responden bersedia mendengarkan saran dan pertimbangan dari pemeluk agama lain; (6) umumnya responden netral dalam kesediaan untuk menjaga normatif usaha yang tidak bertentangan dengan pemeluk agama lain; dan (7) seluruh responden $(100 \%)$ bersedia menghadiri undangan dari pemeluk agama lain.

Sebagian besar responden bersedia mengajak pemeluk agama lain agar terlibat dalam kegiatan yang diadakan. Keadaan ini kemungkinan sangat dipengaruhi oleh kepatuhan umat terhadap ajaran agama, himbauan pemerintah, dan penyuluhan tokoh umat beragama melalui budaya gotong royong yang tetap terpelihara dan menjadi ciri khas seluruh elemen masyarakat dan pemerintah. Hal ini sesuai yang dilaporkan Sodli (2009) bahwa umat beragama di NTT tergolong taat dan patuh terhadap ajaran agama (rukun dan saling membantu), pemerintah yang terus membina dengan semboyan gotong royong, dan tokoh agama yang terus mensosialisasikan kerukunan dan keharmonisan sosial antara umat beragama melalui Forum Kerukunan Umat Beragama (FKUB).

Sebagian besar responden berada pada sikap yang netral jika menyangkut pemberian sumbangan atau aksi sosial kepada pemeluk agama lain karena responden berpersepsi bahwa aksi sosial atau sumbangan merupakan bentuk inklusivitas dari umat beragama. Artinya, pemberian sumbangan dan aksi sosial tidak terlalu penting ditanyakan karena merupakan nilai implisit dari ajaran kebaikan pada setiap pemeluk agama lain. Rejeki Waluyajati \& Farida (2018) menyatakan bahwa adanya perubahan pola interaksi sosial keagamaan dari doktrin yang eksklusivisme ke inklusivisme mengubah tatanan sikap kerjasama dan moral tidak lagi berbasis kesamaan agama tetapi sebagai makhluk yang sama derajatnya sebagai makhluk sosial.

Umumnya partisipasi responden dalam membangun rumah ibadah pemeluk agama lain cukup tinggi di Kota Kupang yang mengindikasikan adanya hubungan sosial antara umat beragama yang sangat baik. Rais \& Makassar (2012) menyatakan bahwa adanya hubungan sosial antar kelompok agama yang baik ditunjukkan melalui kesediaan berinteraksi secara sosial dan personal, salah satunya adalah kesediaan terlibat dalam pembangunan rumah ibadah pemeluk agama lain.

Umumnya responden bersedia memberikan izin kepada pemeluk agama lain untuk berkegiatan yang tidak meresahkan banyak orang karena secara etika dan aturan, kegiatan-kegiatan yang dilakukan oleh pemeluk agama dibatasi oleh kebiasaan-kebiasaan atau norma-norma masyarakat yang telah terpelihara selama turun temurun sebagai akibat dari pergaulan sosial dan penghormatan sosial yang telah berlaku lama dalam masyarakat. Hal ini sesuai dengan pernyataan Abas. M, Khattak. S.B, Akhtar. R, Ahmad.I, Misbah Ullah (2016) bahwa pergaulan sosial dan penghormatan yang bersifat sosial mempengaruhi kebiasaan dan norma untuk saling bergaul dan menghormati ajaran pemeluk agama lain.

Tabel 3. Kerjasama umat beragama

\begin{tabular}{|l|c|cc|c|c|}
\hline \multirow{2}{*}{ Kerjasama } & \multicolumn{5}{|c|}{ Jawaban (\%) } \\
\cline { 2 - 5 } & SS & S & N & TS & STS \\
\hline $\begin{array}{l}\text { Bersedia } \\
\text { mengajak } \\
\text { pemeluk agama } \\
\text { lain untuk } \\
\text { terlibat dalam } \\
\text { kegiatan yang } \\
\text { diadakan }\end{array}$ & 65,2 & 21,4 & 8,9 & 1,4 & 3,1 \\
\hline $\begin{array}{l}\text { Bersedia } \\
\text { memberikan } \\
\text { sumbangan } \\
\text { atau aksi sosial } \\
\text { kepada } \\
\text { pemeluk agama } \\
\text { lain }\end{array}$ & 11,3 & 17,9 & 65,8 & 3,9 & 1,1 \\
\hline
\end{tabular}




\begin{tabular}{|c|c|c|c|c|c|}
\hline $\begin{array}{l}\text { Bersedia } \\
\text { terlibat dalam } \\
\text { pembangunan } \\
\text { rumah ibadah } \\
\text { pemeluk agama } \\
\text { lain }\end{array}$ & 21,9 & 27,5 & 31,1 & 11,6 & 7,9 \\
\hline $\begin{array}{l}\text { Bersedia } \\
\text { memberikan } \\
\text { izin kepada } \\
\text { pemeluk agama } \\
\text { lain untuk } \\
\text { berkegiatan } \\
\text { yang tidak } \\
\text { meresahkan } \\
\text { banyak orang }\end{array}$ & 100 & - & - & - & - \\
\hline $\begin{array}{l}\text { Bersedia } \\
\text { mendengarkan } \\
\text { saran dan } \\
\text { pertimbangan } \\
\text { dari pemeluk } \\
\text { agama lain }\end{array}$ & 80,6 & 18,5 & - & 0,9 & - \\
\hline $\begin{array}{l}\text { Bersedia untuk } \\
\text { menjaga } \\
\text { normatif usaha } \\
\text { yang tidak } \\
\text { bertentangan } \\
\text { dengan } \\
\text { pemeluk agama } \\
\text { lain }\end{array}$ & 5,7 & 6,9 & 67,2 & 11,5 & 8,7 \\
\hline $\begin{array}{l}\text { Bersedia } \\
\text { menghadiri } \\
\text { undangan dari }\end{array}$ & 100 & - & - & - & - \\
\hline
\end{tabular}

Umumnya responden bersedia mendengarkan saran dan pertimbangan dari pemeluk agama lain, karena saran dan pertimbangan merupakan bentuk dari komunikasi di antara manusia yang dipengaruhi oleh karakteristik personal seperti umur dan pengalaman, juga dipengaruhi ajaran agama tentang perbuatan baik yang selama ini menjadi pilar toleransi di Kota Kupang. Saprillah (2016) menyatakan bahwa faktor ajaran agama yang mengajarkan untuk saling menyuruh kebaikan terhadap sesama manusia, usia dan pengalaman dalam menjalani konsekuensi hidup antara umat beragama merupakan faktor yang mempengaruhi kualitas komunikasi dalam kerukunan antar umat beragama.

Responden umumnya memilih netral terkait kesediaan untuk menjaga normatif usaha yang tidak bertentangan dengan pemeluk agama lain. Hal ini kemungkinan sangat dipengaruhi oleh faktor situasi dan kondisi terhadap kebiasaan pemeluk agama mayoritas di Kota Kupang yang umumnya berusaha kuliner makanan yang dikategorikan haram bagi pemeluk agama lain di Kota Kupang. Ahmad Fauzi (2016) menyatakan bahwa umumnya umat beragama yang kaya akan toleransi akan bersikap hati-hati atau netral terhadap sesuatu hal bersifat menciderai nilai-nilai ajaran pemeluk agama lain.

Interaksi sosial dan budaya toleransi yang telah terpola baik di Kota Kupang menyebabkan keeratan hubungan sosial kemasyarakatan. Salah satu bentuknya adalah bersedia menghadiri undangan dari pemeluk agama lain. Richset Riwukore et al. (2021) menyatakan bahwa interaksi sosial kemasyarakatan yang telah terjalin baik merupakan faktor utama kesediaan manusia (umat beragama) untuk terlibat dan berpartisipasi dalam suasana bathin manusia lainnya seperti manusia lainnya sedang mengalami kedukaan, syukuran, baptisan, pesta, dan lainnya meskipun berbeda suku, agama, ras, dan golongan.

\section{Peran Pemerintah Kota Kupang}

Peran pemerintah memang sangat dibutuhkan dalam merawat dan menjaga rakyat agar tidak terjatuh dalam konflik. Peran itu tidak harus selalu berujung pada pembuatan regulasi yang sifatnya multitafsir. Peran itu bisa dilakukan dengan mendorong masyarakat secara mandiri menjaga kerukunan. Peran pemerintah tersaji pada Tabel 1.

Peran pemerintah khususnya di Kota Kupang dalam menjaga dan menjamin kebebasan umat beragama menunjukkan: (1) sejumlah 100\% responden menyatakan bahwa pemerintah memfasilitasi pembangunan rumah ibadah dengan baik; (2) tidak terdapat responden $(0 \%)$ yang menyatakan bahwa pemerintah tidak melaksanakan sosialisasi toleransi umat beragama; (3) hanya sebagian kecil responden $(2,2 \%)$ yang menyatakan tidak setuju sampai dengan sangat tidak setuju bahwa pemerintah aktif dalam memperjuangkan atau menyerap aspirasi umat beragama; (4) lebih dari 91,4\% responden menyatakan bahwa pemerintah aktif dalam membantu umat beragama yang berkekurangan atau membutuhkan bantuan; (5) sebagian besar responden menyatakan bahwa pemerintah aktif dalam membangun komunikasi antar umat beragama; dan (5) lebih dari 94,9\% 
responden menyatakan pemerintah aktif dalam membangun komunikasi antar umat beragama; dan (6) seluruh responden menyatakan pemerintah peduli dengan kebebasan beribadah umat beragama dan pemerintah menjamin terlaksananya kegiatan-kegiatan umat keagamaan. Hasil ini menunjukkan adanya jaminan dan perlindungan pemerintah untuk seluruh umat beragama melaksanakan aktivitas menurut kepercayaan dan keyakinan pemeluk agama.

Tabel 4. Peran Pemerintah

\begin{tabular}{|c|c|c|c|c|c|}
\hline \multirow{2}{*}{$\begin{array}{l}\text { Peran } \\
\text { Pemerintah }\end{array}$} & \multicolumn{5}{|c|}{ Jawaban $(\%)$} \\
\hline & SS & $\mathbf{S}$ & $\mathbf{N}$ & $\begin{array}{l}\mathrm{T} \\
\mathrm{S}\end{array}$ & $\begin{array}{c}\text { ST } \\
\text { S }\end{array}$ \\
\hline $\begin{array}{l}\text { Pemerintah } \\
\text { memfasilitasi } \\
\text { pembangunan } \\
\text { rumah ibadah } \\
\text { dengan baik }\end{array}$ & 100 & - & - & - & - \\
\hline $\begin{array}{l}\text { Pemerintah terus } \\
\text { melaksanakan } \\
\text { sosialisasi } \\
\text { toleransi umat } \\
\text { beragama }\end{array}$ & $\begin{array}{c}27 \\
8\end{array}$ & $\begin{array}{c}48 \\
6\end{array}$ & $\begin{array}{c}23, \\
6\end{array}$ & - & - \\
\hline $\begin{array}{l}\text { Pemerintah aktif } \\
\text { dalam } \\
\text { memperjuangka } \\
\mathrm{n} \text { atau menyerap } \\
\text { aspirasi umat } \\
\text { beragama }\end{array}$ & $\begin{array}{c}80 \\
5\end{array}$ & $\begin{array}{c}13, \\
1\end{array}$ & 4,2 & 0,3 & 1,9 \\
\hline $\begin{array}{l}\text { Pemerintah aktif } \\
\text { dalam } \\
\text { membantu umat } \\
\text { beragama yang } \\
\text { berkekurangan } \\
\text { atau } \\
\text { membutuhkan } \\
\text { bantuan }\end{array}$ & 3,4 & $\begin{array}{c}91 \\
4\end{array}$ & 0,9 & 2,1 & 2,2 \\
\hline $\begin{array}{l}\text { Pemerintah aktif } \\
\text { dalam } \\
\text { membangun } \\
\text { komunikasi } \\
\text { antar umat } \\
\text { beragama }\end{array}$ & $\begin{array}{c}83 \\
5\end{array}$ & $\begin{array}{c}11, \\
4\end{array}$ & 2,7 & 1,9 & 0,5 \\
\hline $\begin{array}{l}\text { Pemerintah } \\
\text { peduli dengan } \\
\text { kebebasan } \\
\text { beribadah umat } \\
\text { beragama }\end{array}$ & 100 & - & - & - & - \\
\hline $\begin{array}{l}\text { Pemerintah } \\
\text { menjamin } \\
\text { terlaksananya } \\
\text { kegiatan- } \\
\text { kegiatan umat } \\
\text { keagamaan }\end{array}$ & 100 & - & - & - & - \\
\hline
\end{tabular}

Keberhasilan Pemerintah Kota Kupang dalam menjaga umat beragama sangat dipengaruhi oleh banyak faktor, di antaranya: (1) budaya toleransi di Kota Kupang yang telah terjaga baik sejak turun temurun; (2) dukungan regulasi yang telah ada; (3) komunikasi yang intens di antara tokoh-tokoh agama melaui Forum Kerukunan Umat Beragama (FKUB); (4) forum-forum pemuda lintas agama yang terus berkomunikasi untuk saling gotong royong; (5) genealogis pencampuran hubungan keluarga yang telah terjadi secara temurun. Halhal tersebut merupakan faktor-faktor yang mendukung pemerintah dalam menjaga toleransi umat beragama di Kota Kupang. FKUB merupakan salah satu lembaga yang sangat membantu Pemerintah Kota Kupang untuk mendesain kebijakan-kebijakan dan dukungan pembangunan berbasiskan toleransi umat beragama di Kota Kupang (Salim, 2017) menyatakan bahwa peran pemerintah dan lembaga keagamaan termasuk tokoh-tokoh agama dalam mendorong kerukunan umat beragama yang berkualitas akan mereduksi konflik berbasis keagamaan dengan memfokuskan diri pada upaya pencegahan konflik agama dalam konsep kerukunan agama.

\section{Kesimpulan}

Hasil penelitian berdasarkan dimensi persepsi umat beragama menunjukkan sebagian besar pemeluk agama berpersepsi agama yang dianut paling benar, ekspresi umat beragama mempertimbangkan norma ekspresi, mayoritas tidak semena-mena terhadap minoritas, agama wajar digunakan dalam isu politik, tidak diperkenankan interaksi sosial berbasis agama, euforia acara keagamaan merupakan hal yang wajar, dan menolak doktrin keagamaan berbasis kekerasan. Berdasarkan dimensi sikap umat beragama menunjukkan bahwa pemeluk agama umumnya bersedia bertetangga dengan pemeluk agama lain, lebih memilih untuk menikah berdasarkan kesamaan agama, terlibat dan berpartisipasi dalam kegiatan keagamaan orang lain, tidak memandang agama dalam menyelesaikan konflik, keberadaan agama lain yang tidak diakui negara meresahkan, merasa terganggu jika terdapat pemeluk agama lain yang berpakaian tidak sewajarnya sesuai tata cara berpakaian agamis, tetapi umat cenderung netral terhadap kesediaan berada di rumah ibadah 
pemeluk agama lain yang ada di sekitar tempat tinggal. Dimensi kerjasama umat menunjukkan adanya kesediaan mengajak pemeluk agama lain terlibat dalam kegiatan yang diadakan, bersedia terlibat dalam pembangunan rumah ibadah pemeluk agama lain, bersedia memberikan izin kepada pemeluk agama lain untuk berkegiatan yang tidak meresahkan banyak orang, kesediaan umat mendengar saran dan pertimbangan dari pemeluk agama lain, dan bersedia menghadiri undangan dari pemeluk agama lain, walaupun dalam beberapa aspek dimensi kerjasama, umumnya pemeluk agama bersikap netral terhadap kesediaan memberikan sumbangan atau aksi sosial kepada pemeluk agama lain, dan juga terhadap kesediaan untuk menjaga normatif usaha yang tidak bertentangan dengan pemeluk agama lain. Selanjutnya, berdasarkan dimensi peran pemerintah menunjukkan bahwa pemerintah memfasilitas pembangunan rumah ibadah dengan baik, pemerintah terus melaksanakan sosialisasi toleransi umat beragama, pemerintah aktif dalam memperjuangkan atau menyerap aspirasi umat beragama, pemerintah aktif dalam membantu umat beragama yang berkekurangan atau membutuhkan bantuan, pemerintah aktif dalam membangun komunikasi antarumat beragama, pemerintah peduli dengan kebebasan beribadah umat beragama, dan pemerintah menjamin terlaksananya kegiatan-kegiatan umat keagamaan.

\section{UCAPAN Terima Kasih}

Ucapan terimakasih disampaikan kepada Yayasan Jeriko Center Kupang yang telah menjadi sukarelawan dalam pengumpulan data penelitian ini. 
Abas. M, Khattak. S.B, Akhtar. R, Ahmad.I, Misbah Ullah, H. I. U. (2016). Identification of factors affecting cost performance of construction projects Technical Journal, University of Engineering and Technology (UET) Taxila, Pakistan, 21(1), 72-78.

Ahmad Fauzi. (2016). Pakaian Wanita Muslimah Dalam Perspektif Hukum Islam. Jurnal Ekonomi Syariah, 1(1), 41-58. http:// ejournal.alqolam.ac.id/index.php/ iqtishodia/article/download/56/61

Ajahari, A. (2018). Aktualisasi Kerukunan Masyarakat Beda Agama di Kelurahan Pager Kecamatan Rakumpit Kota Palangka Raya. Jurnal Studi Agama Dan Masyarakat, 14(2), 72. https://doi.org/10.23971/ jsam.v14i2.936

As'ad, M. (2018). Kehidupan Keagamaan Dan Budaya Mas Yarakat Dikota Jayapura Provinsi Papua. Al-Qalam, 13(2), 85. https:// doi.org/10.31969/alq.v13i2.566

Choli, I. (2018). Perkembangan Jiwa Keagamaan Pada Usia Lanjut. Ix(1), 97-109.

Daeli, D. O., \& Zaluchu, S. E. (2019). Analisis Fenomenologi Deskriptif terhadap Panggilan Iman Kristen untuk Kerukunan Antar Umat Beragama di Indonesia. SUNDERMANN: Jurnal Ilmiah Teologi, Pendidikan, Sains, Humaniora Dan Kebudayaan, 12(2), 44-50. https://doi.org/ 10.36588/sundermann.v1i1.27

Darmawati H, \& Abdullah, T. (2016). Respon Siswa Madrasah Aliayah Terhadap Radikalisme Di Makasar. Sulesana, 10(01), 19-48.

Hafidzi, A. (2019). Konsep Toleransi Dan Kematangan Agama Dalam Konflik Beragama Di Masyarakat Indonesia. Potret Pemikiran, 23(2), 51. https://doi.org/ 10.30984/pp.v23i2.1003

Hapsin, A. (2014). Urgensi Regulasi Penyelesaian Konflik Umat Beragama: Perspektif Tokoh Lintas Agama. Walisongo: Jurnal Penelitian
Sosial Keagamaan, 22(2), 351-380. http:// journal.walisongo.ac.id/index.php/ walisongo/article/view/270

Hermawati, R., Paskarina, C., \& Runiawati, N. (2017). Toleransi Antar Umat Beragama di Kota Bandung. Umbara, 1(2). https://doi.org/ 10.24198/umbara.v1i2.10341

Hidayat, S. (2014). SACRED SCIENCE vs. SECULAR SCIENCE: Carut Marut Hubungan Agama dan Sains. Kalam, 8(1), 87. https://doi.org/10.24042/klm.v8i1.169

Hutapea, B. (2011). Dalam Perkawinan Berbeda Agama ( the Dynamics of Marital Adjustment in the Interfaith Marriage ). Jurnal Penelitian Dan Pengembangan Kesejahteraan Sosial, 16(1), 101-118.

Kasselstrand, I. (2018). Religious Indifference: New Perspectives from Studies on Secularization and Nonreligion. Journal of Contemporary Religion, 33(1), 139-140. https://doi.org/ 10.1080/13537903.2018.1408299

Maulidah, R. (2014). Toleransi Umat Muslim terhadap Keberadaan Gereja pantekosa di Surabaya. Religiol : Jurnal Studi AgamaAgama, Vol. 4, 2(September 2014), 195-217.

Mibtadin, M., \& Hedi, F. (2020). Masjid, Khutbah Jumat, dan Konstruksi Realitas Keagamaan di Ruang Publik: Studi tentang Materi Khutbah Jumat di Masjid-Masjid Kota Surakarta. Jurnal Ilmu Dakwah, 40(1), 40-53. https://doi.org/10.21580/jid.v40.1.5297

Mukzizatin, S. (2019). Relasi Harmonis Antar Umat Beragama dalam Al-Qur'an. Andragogi: Jurnal Diklat Teknis Pendidikan Dan Keagamaan, 7(1), 161-180. https:// doi.org/10.36052/andragogi.v7i1.75

Nasution, A. G. J. (2017). Pendidikan Islam dalam Catatan Sejarah. http://repository.uinsu.ac.id/ 5581/1/Buku SPI.pdf

Nisvilyah, L. (2010). Toleransi antarumat Beragama Toleransi Antarumat Beragama Dalam Memperkokoh Persatuan Dan Kesatuan Bangsa ( Studi Kasus Umat Islam 
Dan Kristen Dusun Segaran Kecamatan Dlanggu Kabupaten Mojokerto ) Lely Nisvilyah ( PPKn , FIS , UNESA ) lelynisvilyah@yahoo. Kajian Moral Dan Kewarganegaraan No. 1, Vol. 2.

Parera, M. M. A. E., \& Marzuki, M. (2020). Kearifan Lokal Masyarakat Dalam Membangun Kerukunan Umat Beragamadi Kota Kupang Nusa Tenggara Timur (NTT). Jurnal Antropologi: Isu-Isu Sosial Budaya, 22(1), 38. https://doi.org/10.25077/jantro.v22.n1.p3847.2020

Putra, P. A., \& Yuliando, H. (2015). Soilless Culture System to Support Water Use Efficiency and Product Quality: A Review. Agriculture and Agricultural Science Procedia, 3, 283-288. https://doi.org/10.1016/j.aaspro.2015.01.054

Rahmawati Zulfiningrum1, Akbar Nuur Purnawa DW2, E. W. (2020). Menuju Dialog Deliberatif Resolusi Konflik: Sebuah Studi Komunikasi Antarbudaya Di Kampung Adat JalaswatU. Jurnal Audience, Jurnal Ilmu Komunikasi, 03, 79-98.

Rais, M., \& Makassar, A. (2012). Indeks Kerukunan Antarumat Beragama di Kalimantan Timur. 19, 189-200.

Rejeki Waluyajati, R. S., \& Farida, L. U. (2018). Pola Interaksi Sosial Keagamaan Antara Penganut Agama Islam Dan Kristen Advent (Studi Kasus di Desa Cihanjuang Rahayu Kecamatan Parongpong Kabupaten Bandung Barat). Religious: Jurnal Studi Agama-Agama Dan Lintas Budaya, 2(2), 8491. https://doi.org/10.15575/rjsalb.v2i2.3097

Richset Riwukore, J., Susanto, Y., Walyusman, W., Riance, A., Zubaidah, R. A., \& Habaora, F. (2021). Analysis of Employee Performance Based on Competence and Work Climate in Lubuklinggau Barat I District at Indonesia. The Journal of Social Sciences Research, 7(71), 7-14. https://doi.org/10.32861/jssr.71.7.14

Salim, D. P. (2017). Kerukunan Umat Beragama Vs Kebebasan Beragama Di Indonesia. Potret Pemikiran, 21(2). https://doi.org/ 10.30984/pp.v21i2.741

Saprillah, S. (2016). Mengukur Indeks Kerukunan Antar Umat Beragama Di Kabupaten
Konawe Selatan. Al-Qalam, 20(2), 269. https:/ /doi.org/10.31969/alq.v20i2.196

Sodli, O. A. (2009). P Enelitian K Erukunan U Mat B Eragama Di P Rovinsi N Usa Tenggara Timur ( NTT ). XVI(01), 64-73.

Suryana, T. (2011). Konsep dan aktualisasi kerukunan antar umat beragama. Pendidikan Agama Islam -Ta'lim, 9(2), 127136.

Tule, P. (2014). Religious Conflicts and a Culture of Tolerance: Paving the Way for Reconciliation in Indonesia. Antropologi Indonesia, 0(63), 1-4. https://doi.org/10.7454/ ai.v0i63.3404 